\title{
A.G. Stakhanov in Gaumont Pathé's Soviet Film Archives: Between Physical Performance and Instrumentalisation
}

\author{
NADÈGE MARIOTTTI \\ University of Lorraine, University of Sorbonne Nouvelle
}

\begin{abstract}
The depiction of the miner A.G. Stakhanov in newsreels from the Gaumont Pathe archives highlights the representations of this physical performance used in the specific economic and political environment of the USSR during the interwar period. The Soviet worker is idealized as a national hero. At that time, the Soviet government was looking for the "New Man" and "new technical standards" (Stalin, 1977) and Stakhanov lost his individuality, becoming "only an official agent of the state" (Vigne, 1984). This article examines the evolution of the memory of Stakhanov's record mining achievement, moving from a retrospective point of view to a celebration and finally to commemoration (Ory, 1992).
\end{abstract}

\section{INTRODUCTION}

Films from the beginning of the $20^{\text {th }}$ century often highlight the danger of mines and factories in order to denounce the strain and suffering experienced by workers. This representation of the worker's body as a tool, an instrument in the ethnological sense of the term, brings man closer to machine. In the USSR, the Bolshevik revolution that set up the foundations of communist ideology depended on an idealised image of human work (Betea, 1995). Under Stalin, searching for the "New Man" was linked to the goal of " - new technical standards - "1. The figure of the Stakhanovite worker was also essential (Betea, 1995). On August 30,1935 , on the occasion of the $21^{\text {st }}$ International Youth Day, Alexeï Grigorievitch Stakhanov, a hewer ${ }^{2}$ in a mine in Donbass, Ukraine, beat the productivity record for extracting coal with a pneumatic drill.

“To celebrate the 21th International Youth Day, comrade Stakhanov, central hewer at the CobraIrmino mine in Kadievka, established a new Soviet productivity record with a pneumatic drill. In a six-hour shift, Stakhanov produced 102 tons of coal, which represents $10 \%$ of the daily output of the mine, and

\footnotetext{
${ }^{1}$ Joseph Stalin, Speech given at the first conference of the Stakhanovites of the USSR on November 17th, 1935.

2 Production consists of extracting the coal by means of a pickaxe or a pneumatic drill. A hewer is a person who extracts coal.
} 
earned 200 roubles. Comrade Stakhanov exceeded Grisin, Sviridov, Murasko, masters of the pneumatic drill who had never been surpassed." (Pravda, September 2, 1935, quoted in Depretto 1982)

The first Soviet five-year plan (1928-1933) produced disappointing results. The goal for coal mining in the second five-year plan (1933-1937) established by the $17^{\text {th }}$ Assembly of the Central Council of the Russian Communist Party was 152 million tons, or $235 \%$ of what had been obtained in $1932^{3}$. Reaching the goal set by the plan thus became a priority. According to Stakhanov, the day before the $21^{\text {st }}$ International Youth Day, the members of the party "collected [the miners'] proposals for improving the organization of work and shortening the working day" (Depretto, 1982). Stakhanov claimed that there was a drop in productivity because the hewer not only extracted coal, but also worked as a timber man. Extracting coal requires timbering ${ }^{4}$ in order for the construction site to be safe. In his book Story of my Life (1938), Stakhanov says that the next day, the members of the party set up the conditions necessary for this new organization of the work, thus enabling him to set the record. These details were not revealed in the press. What did these films show of Stakhanov's achievement? How were they used and reused throughout the $20^{\text {th }}$ Century? Are these images the reflection of a collective memory or rather of a staging of the event by the State?

This study of the figure of Alexei Grigorievitch Stakhanov follows a new perspective on how the Stalinist hero was portrayed. Most previous studies take a historical and economic approach, examining the miner's record through non-film sources in order to show how the Soviet state exploited it. This article uses a different source - documentary film - that was the Soviet leadership's preferred means of communicating to the public. The other original aspect of this study is the use of Gaumont Pathé Archives' Arkéion film collection, only recently made available for research. This approach reveals a development in the cinematic representation of the miner's achievement linked to the regime's concerns about the transmission of a collective memory. In order to understand the three stages of the representation of Stakhanov's achievement, we must first establish the origins of the corpus of films depicting it.

\section{ORIGINS}

Starting in the 1960s, the historian Marc Ferro revolutionized our way of looking at cinema. Instead of seeing films simply as works of art, he considered them as objects that reflect the society in which they were created. Ferro showed that cinema was closely linked to the political and ideological transformations in the

\footnotetext{
3 Published in Iqvestia (The news), December 30, 1933.

${ }^{4}$ Supporting the roof of a gallery by means of wooden logs.
} 
Soviet Union, and that Trotsky, Lenin and other leaders saw cinema as a means of educating the illiterate masses. ${ }^{5}$ This was the objective of the official decree on August 27, 1919 that nationalized the film industry. Cinema became a mass medium for the propagation of ideology. Every film genre was affected, including fiction, documentaries, and newsreels. These ancestors of today's newsreels fulfilled the regime's desire to film daily life and current events ${ }^{6}$ for educational purposes. Pierre Sorlin observes that although films of this type already existed before the October Revolution, the Bolsheviks were the first to use them as an instrument of "persuasion," p particularly with the creation of Agitprop, the Soviet state's official propaganda organization. ${ }^{8}$

Until the 1930s, these films showed not only industrial and agricultural labor but also aimed to show the different regions and peoples of the USSR for public health purposes. The period was likewise marked by the birth of a new genre of judicial films that dramatized and reenacted trials. ${ }^{9}$ Aya Kawamura states that "We can thus speak about a Soviet 'documentary moment' when artists got together and organized 'events' - material taken from real life - collected from the masses, and attempted to represent how Soviet society could be constructed through texts and visual media."10 She argues that "worker and peasantcorrespondents" participated in the writing and distribution of their daily life and work and thus themselves became "the theoretical model" of the Soviet documentary movement. ${ }^{11}$

André Bazin observes that not only certain did fiction films feature historical figures, but that this historical genre became particularly widespread under Stalin. ${ }^{12}$ Soviet cinema underwent a transformation starting in the 1930s as it participated in creating the figure of the "New Man." According to Peter Kenez, while fewer films were produced after the introduction of sound cinema, the rate of documentary production decreased less dramatically than the production of fiction films. ${ }^{13}$ From the beginning of the Second World War to the breakup of the USSR, documentary filmmaking flourished. By the 1960s, however, basic literacy was no longer the problem it once had been, and documentary cinema became

\footnotetext{
${ }^{5}$ Marc Ferro, Cinéma et histoire (Paris: Gallimard, 1977), 140-143.

${ }^{6}$ N.A. Lebedev, Otcherki istorii kino SSSR, Nemoe kino : 1918-1934 gody (Moscow: Iskusstvo, 1965).

${ }^{7}$ Pierre Sorlin, “Archives et acutalités filmées de l'époque stalinienne," Théorème no. 8 (2015): 290.

8 "Agitprop" is an abbreviation for the organization's full name, which translates as "Agitation and propaganda." This ideology, created at the end of the 19th century, was first applied to cinema by the writer Anatoly Lunacharsky. In turn, Lenin himself was inspired by it. François Albéra, "Cinéma soviétique des années 1924-1928 : commande sociale/commande publique," in Une bistoire mondiale des cinémas de propagande, ed. Jean-Pierre Bertin-Maghit (Ville: Maison d'édition, année), pages.

9 Oleg Kovalov, "Noveichaya istoria otetchestvennogo kino. 1986-2000. Kino i kontext. T.IV.” SPb, in Seance, 2002.

10 Aya Kawamura, "La création collective dans le documentaire soviétique : photographie, cinéma et 'correspondants-ouvriers," 1895. Mille buit cent quatre-vingt-quinze no. 63 (2011), doi: 10.4000/1895.4323.

${ }^{11}$ Ibid., 50.

12 André Bazin, “Le cinéma soviétique et le mythe de Staline,” Esprit no. 170 (August 1950): 210-235.

${ }^{13}$ Peter Kenez, "Le cinéma soviétique sous Staline (1928-1953),” Théorème no. 8 (2005): 19.
} 


\section{Mariotti - A. G. StAkHANOv in Gaumont Pathé’s Soviet Film ARChives: Between Physical PERFormanCE AND INSTRUMENTALISATION}

oriented toward informing rather than educating the public. ${ }^{14}$ In the $20^{\text {th }}$ Century, filmmakers such as Boris Barnet, Alexandr Dovzhenko (war documentaries), Mikhail Kalatozov, Dziga Vertov (montage films) and Alexandr Medvedkin (ciné-train) all marked Soviet documentary both with the subject matter of their films and with their aesthetic value. "The very specific style of Soviet propaganda films could never have existed in another political system."16 Nevertheless, research conducted since the early 2000s has brought greater nuance to the overall impression of Soviet propaganda, especially Stalinist propaganda. Books edited by Bernard Eisenscihtz, ${ }^{17}$ Natacha Laurent, ${ }^{18}$ Kristian Feigelson, ${ }^{19}$ and Jean-Pierre Bertin-Maghit ${ }^{20}$ have put into perspective the uniformity of Soviet cinema: "beneath the surface of uniform production ... rough patches, divergences, even spaces of autonomy" appeared. ${ }^{21}$ The study of movie theaters, film scripts, genres like musical comedy, female stars, as well as the relationship between aesthetics, politics, economics and technology in film and non-film archives has shown how Stalinist cinema shifted and evolved much more than previously thought.

During Perestroika, from 1986 to 1990, Mikhail Gorbachev set up a more open communication policy, which revolutionized Soviet cinema (Godet, 1991). The state monopoly on film production disappeared and market forces took over. Foreign distributors of Soviet films, which relied on the old system, likewise vanished. This was the case of Audiphone, the distribution company for Soviet movies in France, which became Cosmos Film ${ }^{22}$ (Samier, 2012). In 1991, Cosmos ceded its assets to Arkéion Films. After the fall of the Berlin Wall and the breakup of the USSR, this company specialized in the purchase of films from Eastern Europe (Massignon, 2002). Then, in 2003, the Cinémathèque Gaumont took over the management Arkéion Films' documentary collection, ${ }^{23}$ which consists of "more than 1,500 hours of 35 $\mathrm{mm}^{24}$ films" originating from Russian and Soviet archives from 1910 to 1980, dealing with the USSR, Cuba, China, Vietnam, and Yugoslavia, as well as France and Spain in the 1930s. Also in 2003, the Cinémathèque

\footnotetext{
${ }^{14}$ Katia Khazak, Le cinéma de la perestroika vu par la critique de presse française, M.A. Thesis, (Université Sorbonne Nouvelle - Paris 3 , 2008).

${ }^{15}$ According to Elizabeth Papazian, Soviet culture was significantly infludenced by the aesthetics of documentary cinema.

${ }^{16}$ Kenez, 32.

${ }^{17}$ Bernard Eisenschitz (ed.), Gels et dégels. Une autre histoire du cinéma soviétique, 1926-1968 (Paris: Centre Pompidou, 2002).

18 Natacha Laurent (ed.), Le cinéma stalinien, question d'histoire (Toulouse: Presses Universitaires du Mirail/La Cinémathèque de Toulouse, 2003).

${ }^{19}$ Kristian Feigelson (ed.), Caméra politique. Cinéma et stalinisme (Paris: Presses de la Sorbonne Nouvelle, 2005).

${ }^{20}$ Jean-Pierre Bertin-Maghit (ed.), Une histoire mondiale des cinémas de propagande (Paris : Nouveau Monde Éditions, 2008).

${ }^{21}$ Laurent, 11.

22 The company was called Cosmos Film beginning in 1980, and went out of business in 1986. In 1978, at the time of its creation, is the company was named Audiphone. "The first activity of the company Audiphone was to simultaneously establish a catalog of French movies to be sold to Soviet customers and a collection of Soviet movies to be sold in France.” (Samier, 2012).

23 Arkéion Films went out of business in 2011.

${ }^{24}$ http://www.gaumontpathearchives.com/index.php?html=108
} 
Gaumont and Pathé Archives merged their catalogs and established Gaumont Pathé Archives ${ }^{25}$. Today, Gaumont Pathé Archives' website gives researchers access to a database including 250,000 film archives.

Searching for the keyword "Stakhanov" in the online database produces a list 23 films with a reference to the famous hewer. Only seven of these films include images of Stakhanov. Five come from the Gaumont Arkéion collection, one from Pathé news and one from the Gaumont documentary collection. Four are from newsreels and three from documentary films. These films show the evolution in the perception of Stakhanov's achievement in three phases: first, a cinematic approach to the mining record, then the achievement's consequences for the hero, and finally the reuse of the event for propaganda purposes.

\section{A Retrospective Approach ${ }^{26}$}

Le journal de l'année $1935^{27}$ is a documentary produced by the Cinémathèque Gaumont in 1993. The film's director, Gilles Delannoy, uses only images taken from newsreels ${ }^{28}$ of the time. Although the editing took place long after the events, the images themselves deserve a serious analysis. In a few seconds, the commentator Gilles Schneider introduces Stakhanov's achievement.

“...Indeed, disorganization and lack of care for work were the plagues of Soviet industry. If we put aside the propaganda images of the great achievements, everything was going wrong. 'Man is the most precious form of capital,' according to Stalin. Man is also much cheaper than machines. To make the masses obedient and orient them toward work, a glorious example was necessary. On August 30, the miner Stakhanov extracted 102 tons of coal using a pneumatic drill, 14 times the usual amount. He was congratulated. He became a hero, a member of the privileged class. An unprecedented fever then seized the whole country, a fever for production: Stakhanovism ..."

The commentary of this scene lasts a total of nineteen seconds. The facts were exposed in an identical way in a Pravda article on September 2, 1935, quoted previously. The article confirms the coal industry's difficulties achieving the goals set in the five-year plans. However, it does not mention the

\footnotetext{
25 http:/ / www.gaumontpathearchives.com/index.php?html=4

26 ORY P. (1992), Une nation pour mémoire 188919391989 trois jubilés révolutionnaires, Paris, Presses de la Fondation nationale des sciences politiques, pp. 7-9. In French, the author uses the term "rétrospection," which translates roughly as "looking back".

27 The news of year 1935 .

${ }^{28}$ In the end credits it seems that the used documents come from the Cinémathèque Gaumont, the advertising archives of the Cinémathèque J.M. Boursicot, posters and photos of Ciné Plus.
} 
favorable conditions that made the record possible, nor the new organization of work that came along with it.

The duration of the images of Stakhanov is short: only seven seconds for five shots. Stakhanov is first shown in a medium close-up shot that lasts for 39 frames, representing his face and his work technique. In his book, A.G. Stakhanov $(1938)^{29}$ describes his work.

“...After making sure that everything was all right, I would dig a 35-40 centimeter cut. Once this niche is cut it is easier to extract the coal. I would make the cut with one hand by following a small vein of coal from the bottom up and with the other hand I would hold the rock above $\mathrm{it}^{30}$. After that, I would cut a niche at the top for a single timbering and extract the layer. The hammer sank so deep into the layer and removed so many blocks of coal that it shined when I held it in my hands. Once I had removed the top of the mass of coal and when I had begun to remove the bottom, both timbermen would go to work."

By comparing this account with the 39 frames, it is possible to situate Stakhanov's filmed actions within the process he describes. Apparently, the sub-cellar has already been built. The film shows the second phase in which the hewer pushes the pneumatic drill. The last image does not show the piece of coal collapsing. Stakhanov's chest and head are slightly bent to the right, and he is wearing a cap. The pneumatic drill penetrates the rock horizontally at shoulder level. His right hand holds the handle of the machine and pushes it into the rock, while his left hand supports it from underneath.

This description confirms that these news images, which probably date from 1935, were not shot live but later on. The framing suggests that the camera was set up in a relatively flat gallery. Yet Stakhanov explains in his book that the interior of the coal mines were strongly sloped, forcing the miners to work on benches. Furthermore, there only seems to be a very small amount of ore extracted in the sequence. The scene must therefore be a reenactment. The image is well framed, highlighting the hewer's face, his half-open mouth, as well as his hands on the pneumatic drill. The drill penetrates the rock face so little that Stakhanov appears to be posing. The medium close-up, which frames the worker's upper body, stresses his actions. The second shot lasts for 36 frames. It shows coal moving forward on a conveyor belt. ${ }^{31}$ By placing this shot directly after the one of the miner in action, the montage suggests that Stakhanov extracted the coal continuously moving on the belt and its quantity makes his achievement appear extraordinary. The third shot, taken from a wider angle, shows Stakhanov exiting the mine. The shot, which lasts for 36 frames, shows him moving

\footnotetext{
29 Translation quoted in French by Jean-Paul Depretto (1982).

30 According to Etienne Gelas, engineer at the Roche-la-Molière and Firminy Mining Company: "The miner cannot make a commitment under the massif. He has to work the coal with his hand held out. He always has to hold his free hand against the rock, which overhangs him to feel it coming". In both cases, the position of the miner and his arms is identical, security.

31 A conveyor belt is a flat surface moved by a motor. It transports the ore from the extraction site towards the surface for transport.
} 
towards the daylight. A crowd waits for him outside of the mine, their arms raised in applause. They greet him by removing their hats. The camera, placed above the crowd, frames Stakhanov. This shot underlines the atmosphere and the welcome reserved for the miner. Everyone seems impressed by the record. Nothing in these images questions Stakhanov's extraordinary record or achievement. ${ }^{32}$

“... and if I succeed, I shall be as famous as Grisin. Grisin is a hewer from the nearby mine, who was decorated with the order of Lenin for his good work and high productivity. Everybody in the city knew Grisin and respected him. 'Grisin?' my wife spoke again. 'How is Alesa inferior to Grisin? Think about it, Grisin can do it and Stakhanov couldn't?" (Stakhanov, 1938) ${ }^{33}$

According to the Pravda article from September 2, 1935, “...comrade Stakhanov surpassed the pneumatic drill masters Grisin, Sviridov, Murasko, who had never been surpassed until now." These records seem well-known. They were posted on the walls of the miners' break room (Depretto, on 1982).

The following shot lasts for 29 frames. A medium close-up shows a man with a gray beard wearing a cap. He applauds. His appearance recalls the emblematic figure of the Russian farmer used to promote the collectivization of land and forced grouping of farmers in kolkhozes (Werth, Berelowitch, 2011). In 1935, Soviet industries were facing a massive influx of rural peasants seeking work. ${ }^{34}$ Huge numbers of farmers, illiterate and with little training in manufacturing experience, moved into the cities of the USSR (Unfried, 1999). This image is intended to work as propaganda to counter the disorganization of the agricultural production system.

The last frames again present Stakhanov in a close-up. Smiling and holding a bouquet, he slowly turns his head from left to right. The shot ends with this view of his face looking directly at the camera. In the background, the crowd is still applauding. The reenactment has reached its climax and Stakhanov is a hero, a link between the reality of labor and the Soviet ideological ideal.

In 1950, Maurice Halbwachs argued that individual memories are confronted with multiple collective memories and are shaped by means of these interactions. Relying on images and accounts of other miners (who may or may not have written records of the events), Party members, Stakhanov and his family, and the crowd attending the youth celebration, the director of the film Journal de l'année 1935 are fully subject to other visions. The image of the event, which he presents, is already the representation of a collective memory. Among the "three phases of collective memory" distinguished by Pascal Ory, this film

\footnotetext{
32 In the episode "The Soviet worker, the hero and the victim" of the radio program The March of History on France Inter, May 1, 2013 , Galia Ackerman explains that Stakanhov was almost certainly not the only hewer on the day the record was set. Others helped him to extract 14 times the normal amount of coal.

${ }_{33}$ Translation quoted by Jean-Paul Depretto (1982).

${ }^{34}$ In 1932-1933 Ukraine in particular was ravaged by famine.
} 


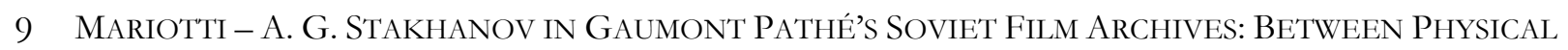
PERFORMANCE AND INSTRUMENTALISATION

corresponds to "looking back" 35 at the achievement: "[it] is of social nature and defines itself as collective shape of the recollection" (Lavabre, 1994, p.483).

\section{Stakhanov, National Hero: The “Celebration"36 of a Collective Memory}

Two films from the Gaumont-Pathé collection evoke the consequences of the record for A.G. Stakhanov. The first film is a montage of Soviet news footage entitled Archives $n^{\circ} 57^{37}$ At two minutes and eleven seconds Joseph Stalin appears in a medium close-up. The footage is taken from the first assembly of the Stakhanovites in Moscow on November 17, $1935 .{ }^{38}$ On May 4, 1935, in a speech pronounced at the Red Army Academy's annual graduation ceremony, Stalin explained that technology without man is nothing (Stalin, 1977). The first assembly of the Stakhanovites was the opportunity for him to put forward this theory of the "new man":

“... Here in front of you are men such as comrades Stakhanov, Boussyguine, Smetanin, Krivonos, Pronin, the Vinogradovas, and many others, new people, men and women workers, who have completely mastered the techniques of their occupations, who have harnessed them and driven them forward. Hardly three years ago, we had no one like them...” (Stalin, 1977).

In turn, A G. Stakhanov speaks: "How did we begin to work in this way? With how many people? Before, we had 23 workers and now our objective is for five workers to perform the work of 23. We don't have enough work for 20. It is actually a relief. Now, what do we receive for this work? If before we received - at least what I received was 450 roubles - today in our mine we manage to earn up to 200 roubles more."39

He expresses himself without inhibition. The speech is short (35 seconds), but allows us to understand how the system could benefit not only from Stakhanovism but also celebrating the worker as an individual: the party intended to reward its most fervent workers in various ways. In his memoir (1938), Stakhanov indicates that the mine's Party committee rewarded him with a bonus equal to his monthly salary, a furnished apartment, a horse, a vacation at a sea resort and tickets for live performances (1938).

The extract begins with an intertitle indicating Stakhanov's name and the name of the mine where he works. In order to show the face of the hero, the camera shows him in a medium close-up as he stands at the

35 Op. cit. Pascal Ory, 7-9. In French, the author uses the term « rétrospection ».

${ }^{36}$ Ibid.

${ }^{37}$ This film is part of the Gaumont Arkéion documentary collection.

${ }^{38}$ This speech, cut into six different pieces, is included in different films. Stalin's speech begins in $A$ rchives $n^{\circ}$ 63. It continues in Archives $n^{\circ} 41,50,57$, and 59 and ends in the film Archives $n^{\circ} 45$. These complations almost certainly consist of rushes.

${ }^{39}$ French translation taken from Archives $n^{\circ} 63$, Gaumont Pathé archives. 
podium. He is dressed in a jacket, shirt, and tie. His face is expressive, and he gestures with his right hand at various points during the speech. He aims to be persuasive. His gaze, however, constantly moves from left to right and back again. Is he looking across the room to make sure the audience is paying attention? Is it a sign of a certain apprehension? Nothing in his attitude allows us to be certain.

At this assembly, Stakhanov was given the title of national labor hero. These few shots are of major importance because they mark the passage from the celebration of his individual performance to its mass instrumentalisation.

This transition is confirmed in the following extract, a documentary with the title Alexei Stakhanov, ouvrier russe devient députe ${ }^{40}$. The documentation accompanying the film marks the footage as "1930-1940," so the exact date is unknown. The film lasts one minute and thirty-four seconds. A title card announces the character's new status as a hero: the words "Alexei Stakhanov" appear against the background of a steel mill. There is no longer any need to specify who he is; it is an obvious fact. The silent film consists of three different parts. The first scene contains five shots. In a medium close-up, Stakhanov appears in front of a chalkboard where he is making calculations. He first looks at the camera, waits, then turns to the board. He seems to be explaining his calculation.

The second shot shows two other men busily working at a table in the classroom. A teacher takes his place behind them and examines what they are writing. The camera then shows Stakhanov in a close-up working on an exercise. His jacket is decorated with several medals. The Order of Lenin, given to workers who have made a special achievement in their profession, is clearly visible. To its right is the Order of the Badge of Honor, awarded starting in 1935 to citizens who have excelled in the economic field. Below, less visible in the frame, is most likely a medal awarded to the Order of the Red Flag of Labor. A flag can be seen at the top of the medal.

Then, in the fourth shot, a young woman is filmed in close-up; she is wearing a jacket and tie. The following scene reveals that she is Stakhanov's wife. A final shot shows them sitting next to each other at a table. The camera films them from their right and shows them writing in profile. The teacher, opposite, leans toward the miner.

In the following scene, the couple enter their home, put down their school bags and settle down on the sofa with their children, a girl and a boy. They are elegantly dressed and play with toys that are visibly luxurious for the time. It is a moment of affection, showing that the miner has time to dedicate himself to his family. All four of them have beaming faces.

40 Alexei Stakhanov, a Russian Worker Becomes a Delegate. 
The final scene presents Stakhanov at his desk. His wife joins him. Together they fill in documents and read the mail. The last shot shows Stakhanov in a close-up writing with a fountain pen.

The editing of the film aims to show the hewer's path not only as an individual, but also as a national labor hero. In his speech to the 1935 Assembly of Stakhanovites, Stalin justifies the existence of such a film.

“... Take a closer look at the Stakhanovite comrades. Who are these people? They are mainly men and women workers, young or middle-aged, developed people, trained in technology, who give the example of precision and attention to work, who know how to appreciate the time factor at work and who learned to count not only in minutes but also in seconds. Most of them have passed what is called the technical minimum [Technical level of knowledge established for workers in socialist enterprises (Translator's note)] and are continuing their technical instruction. They are exempt from the conservatism and routine of certain engineers, technicians and managers; ... they constantly complete and correct the engineers' and technicians' work; they often impress and push them forward because they are men who have fully mastered the technology of their jobs, and they know how to get the most that they can from technology. ..." (Stalin, 1977).

The Stakhanovite, the "New Man" referred to by Stalin, must be educated. Starting in 1936, Stakhanov himself studied at the Industrial Academy of Moscow and went on to a career occupying major posts at the ministry of coal mines and in various industries This new policy was a total reorganization of Soviet industry, where power had previously been concentrated in the hands of engineers who were heavily criticized for their ineffectiveness. ${ }^{41}$ Returning to the film, the title refers to Stakhanov as a delegate. According to the Soviet Constitution of 1936, this means that he had a seat in one of the parliamentary houses $^{42}$ making up the Supreme Soviet of the USSR. The first session of the Supreme Soviet began January 17, 1938 (Gicquel and Gicquel, 2010). It is logical to imagine that the film was shot at that time.

Finally, the film also honors the Stakhanovs as a couple. It is reminiscent of the colossal steel representation of Soviet heroes appearing atop the Russian pavilion of the 1937 World's Fair in Paris. Both figures move forward, the worker brandishing a hammer in his hands, the kolkhozian with a sickle in hers. Similarly, the couple formed by the Stakhanovs prefigures the economic alliance and the institutionalized state model. The presence of women is a recurring theme in Stalinist propaganda.

A progression is visible in these images. A.G. Stakhanov is no longer a miner who has beaten a record but an ideological instrument of the Soviet state. His image has been made into an icon. This film

\footnotetext{
${ }^{41}$ Galia Ackerman in the broadcast The march of history on France Inter on May 1st, 2013 and entitled The Soviet worker, the hero and the victim.

${ }^{42}$ The Soviet of the Union and the Soviet of the Nationalities.
} 
12 Mariotti - A. G. Stakhanov in Gaumont Pathé’s Soviet Film Archives: Between Physical PERFORMANCE AND INSTRUMENTALISATION

thus represents the second phase of collective memory described by Pascal Ory: the phase of "celebration," " which is "of a political nature and expresses a political will" (Lavabre, 1994, p. 483). The last four films of the corpus allow us to understand one last form of use of Stakhanov's image.

\section{Propagandistic Re-USE ${ }^{44}$ OF News IMAgEs: The “Commemoration” ${ }^{45}$ OF A COLlective MEMORY}

According to Eric Vigne (1984), Stakhanov lost his individuality only to become "an agent of the state". Does news footage of Stakhanov confirm this assertion? Certainly, the previous films show the replacement of the man who set the mining record by an instrumentalisation of his image. Did this reality continue in Soviet history or did it disappear over the years, as one economic and political plan replaced another?

Four films from the corpus can help us answer these questions: Bataille pour notre Ukraine (1943), Arcbives ñ 01 (1960), La voie des siècles (1977), and Ce qu'ily a de plus cher, épisode 2: Reconstruction (1981). ${ }^{46}$

All four belong to the Gaumont Arkéion documentary collection, and they all put forth a propagandistic discourse. Bataille pour notre Ukraine is a retrospective of the period from 1941 to 1943, illustrated by newsreel footage. In the second film, the compiled newsreel images recount various events of the 1960s such as the reciprocal visits between the Soviet and American heads of state. La voie des siècles is a Soviet documentary, made on the occasion of the sixtieth anniversary of the October Revolution. It consists largely of newsreel images. Finally, Ce qu'il y a de plus cher, another Soviet documentary, was made to celebrate the thirtieth anniversary of the end of the World War II and forty years of Stakhanovism. The film is a montage alternating news footage and interviews.

These four films, as well as the previously mentioned Le journal de l'année 1935, all invoke the image of the miner Stakhanov. Nevertheless, he is not the main subject of any of them; instead, he is a part of a broader thematic reconstruction.

Generally speaking, all the scenes referring to Stakhanov's record are short, lasting only seven to fifteen seconds. This is to be expected given that these films are not relating a new achievement but recalling an event considered as the founding of Stakhanovism. When comparing how Stakhanov is pictured extracting coal in the five extracts, nuances appear. Four of the films have footage in common. Stakhanov is

\footnotetext{
43 Op. cit. Pascal Ory, 7-9.

${ }^{44}$ Term defined by Laurent Véray with respect to the use of stock footage in Les images d'archives face à l'bistoire, pp. 99-185.

${ }^{45}$ Op. cit. Pascal Ory, 7-9. In French, the author uses "commémoration ". We can translate by "Remembrance".

${ }^{46}$ Battle for our Ukraine; Archives 01; Path of the Centuries; What is dearest, episode 2: Reconstruction.
} 
shown in the mine, in the same posture previously described. As he is framed in a medium close-up, his face is visible at the same time as the to-and-fro movement of his hands as he pushes the pneumatic drill into the ore.

In detail, however, the chosen images are not always identical. Three extracts show the miner's mouth half-open; sometimes the coal collapses, sometimes not. The number of frames is similar only in two cases out of three. The extract from Bataille pour notre Ukraine shows the miner with his mouth closed. In Archives $n^{\circ} 01$, both type of representations are used: mouth open and closed.

Only Ce qu'ily a de plus cher includes unreleased footage of Stakhanov at the mine. The miner is framed in a medium shot that cuts off just above his knees. His back is turned to the wall and he faces the camera. His head is turned to the left, facing the pneumatic drill. His left knee is bent, his body weight placed on it. He holds the handle of the machine while pushing with his right hand, while his left hand maintains it from underneath. Another miner stands outside of the frame. Only a lamp and the right hand holding it appear on screen to the right of Stakhanov. From time to time, the other miner's face comes into the frame. Once again, the scene is reenacted in order to immortalize the event. There is room above the heads of the miners, the ground is flat, the gallery is wide and Stakhanov's posture would be impractical if he were truly extracting coal.

In all the movies, the most commonly used images are thus the ones where the miner's mouth is half open and he seems to be smiling. He seems to do his work effortlessly. The presence of the conveyor belt in three of the extracts helps to present Soviet industry as modern and mechanized.

The shots of the hewer leaving the mine and being greeted by the crowd are present in almost all the films. Ce qu'ily a de plus cher is the only exception. Its editing emphasizes the flowers given to Stakhanov and his joy at receiving them. The image of Stakhanov holding flowers in his hand is the only common shot in all four extracts.

In these images, including those of Stakhanov leaving the mine and receiving the flowers, there is a definite emphasis on how the record-setting miner is greeted and received. The aim is to encourage other workers to emulate Stakhanov and attempt the impossible themselves.

In each of the films, a spectator is shown in a close-up. In one case, it is a young boy: a symbol of youth, an emblem of the future Stakhanovite worker and an icon of the regime. The other films show the face of the bearded man present in Le Journal de l'année 1935. His appearance in these other films tends to confirm the hypothesis that he represents the new workers who have recently arrived from rural areas and must be educated in Stakhanovism. 
Altogether, although the editing is different, the order of scenes is basically the same. The miner beats the record by extracting the ore in the mine. He is then applauded and decorated with flowers by the crowd, private individuals, upon exiting the mine. The story becomes a legend; the image becomes an icon. Two films are particularly similar: Le Journal de l'année 1935 and La voie des siècles. Only an additional shot of the conveyor belt appears in the latter. Given the similarity, it is clear that the French documentary Le Journal de l'année 1935, released in the 1993, reuses the editing from the 1977 Soviet film La voie des siècles.

In the three documentaries ${ }^{47}$, the voiceover commentary is in French, even though two of them are Soviet. The discourse of these two films is quite different from that of Journal de l'année 1935. For La voie des siècles, the voiceover accompanying the images of the miner quickly summarizes the benefits of the economic plans implemented, while citing Stakhanov's record.

"...The first five-year plans allowed a socialist attitude toward work to emerge and assert itself. Alexei Stakhanov, who had pulverized the records of coal mining, was imitated by thousands of workers...."

The first part of the commentary is accompanied by the images of the conveyor belt and then by Stakhanov exiting the mine. When his name is spoken, the screen shows the smiling face of the miner, flowers in his hand. The end of the text is illustrated by images of a steelworker. In Ce qu'ily a de plus cher, the voiceover adheres perfectly to the images.

“...This is how it began ... The miner Alexis Stakhanov extracted 102 tons of coal instead of the usual 7 to 8 tons ..."

The sober, minimal text announces the achievement. Here again the aim is to revive memories. In both cases the idea that Stakhanov is the real initiator of the Stakhanovite movement is demonstrated by the use of expressions such as "has been imitated" or "This is how it began".

The French documentary, which tends not to engage in propagandist discourse, nevertheless describes the achievement without questioning it. The tone of its commentary shows a real distrust in Soviet propaganda. Made in 1993, after the collapse of the USSR, its discourse is necessarily different.

The two Soviet documentaries recall the origin of the events, perpetuating the legend which justified an economic system that was already failing by the late 1970s and early 1980s, when these films were made. The commentary in Ce qu'il y a de plus cher confirms this fact alone. It shows Leonid Brezhnev greeting the first Stakhanovites on the $40^{\text {th }}$ anniversary of Stakhanovism. He states: "I am a man from the time when the party began to speak about Stakhanov. He had given a good start. We still say: 'work like Stakhanov, work like high impact workers.' The movement is immortal."

\footnotetext{
${ }^{47}$ Le Journal de l'année 1935 ; La voie des siècles; Ce qu'ily a de plus cher.
} 
These four films ${ }^{48}$ are examples of "commemoration," 49 the last phase of collective memory theorized by Pascal Ory. This phase is a cross between a "celebratory core" and "echoes of the eventelement in the nation's intellect and sensibility. "It belongs to "this big symbolic movement by which a community defines and strengthens its identity" (ORY, 1992, p.9).

The re-use of newsreel footage of Stakhanov's performance shows that the representation of his achievement underwent a transformation. Although a discourse recounting the events is present in all of the films, Stakhanov's physical presence gradually disappeared. His personal achievement became the nation's. Having become an iconic figure of national labor, Stakhanov's personality faded, giving way to the "serialized" figure of "an agent of the state" (Vigne, 1984). In the end, all of the Stakhanovites in these films have the same face. Only the heroic myth was passed down over time as a model for the USSR's five-year economic plans until the system collapsed.

The memory of the achievement evolved, too, successively moving through the stages of "looking back," "celebration," and "commemoration" (ORY, 1992). It would be interesting to compare these older documentaries with contemporary films to see if this remembrance continues even today, more than twenty years after the fall of the communist regime. However, as early as the 1980s, the image of Stakhanovism in the USSR began to be disintegrate as it was increasingly considered an instrument of Stalinist propaganda. In 1988, the daily Komsomolskaya Pravda ("Truth of the Komsomol') announced that while Stakhanov had extracted the coal by himself, two of his comrades had worked on reinforcing the walls of the gallery. It should be noted, however, that at the time, the Soviet Union had not yet disappeared, and the journalists of Komsomolskaya Pravda did not dare to criticize the deceased too harshly. At his death in 1978, the city of Kadievka was renamed as Stakhanov in his honor. It is now known that Stakhanov's "achievement" was organized in advance by the Communist Party of the Tsentralnaya-Irmino mine. At the time, the mine only had low-quality equipment, lacked skilled workers, and therefore failed to meet its quotas. This was the context in which Stakhanov was introduced, given the best possible equipment, and assisted in his task by many workers, not only charged with reinforcing the walls of the mine, but also extracting the coal and bringing it back to the surface.

\footnotetext{
${ }^{48}$ Bataille pour notre Ukraine; Archives $n^{\circ} 01$; La voie des siècles and Ce qu'ily a de plus cher, épisode 2: Reconstruction.

49 Op. cit. Pascal Ory, 7-9. In French, the author uses "commémoration".
} 
16 Mariotti - A. G. StakHanov in Gaumont Pathé’s Soviet Film ArChives: Between Physical PERFORMANCE AND INSTRUMENTALISATION

\section{REFERENCES}

ALBERA F., LE FORESTIER L., TURQUETY B. (2013), «Archives », in 1895. Revue d'bistoire du cinéma, n69, Paris, AFRHC, p. 96-136.

ALBERA F. (2008), "Cinéma soviétique des années 1924-1928: commande sociale/commande publique », Une histoire mondiale des cinémas de propagande. Jean-pierre Bertin-Maghit (sous la direction de) Monts : Nouveau Monde Éditions.

ARMOGATHE D. (2003), "Pour une didactique de l'archive filmique », in 1895. Revue d'bistoire du cinéma, $n^{\circ} 41$, Paris, AFRHC, p. 145-156.

BAZIN A. (1950), «Le cinéma soviétique et le mythe de Staline », in Esprit, Nouvelle série, No. 170 (8), pp. 210-235.

BERTIN-MAGHIT J-P. (dir.) (2008), Une histoire mondiale des cinémas de propagande. Monts : Nouveau Monde Éditions.

BETEA L. (1995), Maurer et le monde d'hier. Témoignages sur la stalinisation de la Roumanie, Arad, Fondation Ioan Slavici, p. 123-129.

CNC-Archives françaises du film, Conservation [en ligne]. Disponible sur http://www.cncaff.fr/internet_cnc/Internet/ARemplir/Conservation.aspx?Menu=MNU_ACRCHIVES_5 [accessed 12 December 2014].

DEPRETTOO J-P. (1982), «La réalité du stakhanovisme ou Staxanov par lui-même», in Revue des études slaves, Tome 54, fascicule 3, p. 337-343.

EISENSCHITZ B. (dir.) (2002), Gels et dégels. Une autre histoire du cinéma soviétique, 1926-1968, Paris, Centre Pompidou. 
17 Mariotti - A. G. Stakhanov in Gaumont Pathé’s Soviet Film ArChives: Between Physical PERFORMANCE AND INSTRUMENTALISATION

FEIGELSON K. (dir.) (2005), Caméra politique. Cinéma et stalinisme, Théorème n8, Paris, Presses Sorbonne Nouvelle.

FERRO M. (1977), Cinéma et histoire, Folio Histoire, Gallimard.

GAUMONT PATHE ARCHIVES, Documentaires Arkéïon [en ligne]. Disponible sur http://www.gaumontpathearchives.com/index.php?html=108 [accessed 10 January 2015].

GAUMONT PATHE ARCHIVES, Historique [en ligne]. Disponible sur http://www.gaumontpathearchives.com/index.php?html=4 [accessed 10 January 2015].

GELAS E. (1943), «L'abatage au marteau-piqueur », in Revue de la Société de l'industrie minérale, SaintEtienne, p. 11-18.

GICQUEL J., GICQUEL J-E. (2010), Droits constitutionnel et institutions politiques, Paris, Montchrestien-Lextenso Editions.

GODET M. (1991), «Le cinéma soviétique à l’heure de la Perestroïka », in Vingtième siècle, n² 29, p. 85-89.

HALBWACHS M. (1968), La mémoire collective, Paris, PUF, p. 140-153.

KENEZ P. (2005), " Le cinéma soviétique sous Staline (1928-1953) », in Camera politique : cinéma et stalinisme., FEIGELSON Kristian (sous la direction de), Théorème nº, Presses Sorbonne Nouvelle, p. 19.

KHAZAK K. (2008), Le cinema de la perestroika vu par la critique de presse francaise, Master, Université de Paris III, Paris, Sorbonne Nouvelle.

KOVALOV O. (2002), Noveichaya istoria otetchestvennogo kino. 1986-2000. Kino i kontext. T.IV., SPb, in Séance. 


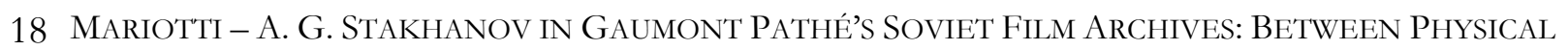
PERFORMANCE AND INSTRUMENTALISATION

LAURENT N. (dir) (2003), Le cinéma stalinien, question d'histoire, Presses univ du Mirail/La cinémathèque de Toulouse.

LEBEDEV N.A. (1965), Otcherki istorii kino SSSR, Nemoe kino: 1918-1934 gody. Iskusstvo, Moskva.

LE ROY E. (2013), Cinémathèques et archives du film, Paris, Armand Colin.

MASSIGNON V. (2002), La recherche d’images. Méthodes, sources et droits, Bruxelles, De Boeck.

ORY P. (1992), Une nation pour mémoire 188919391989 trois jubilés révolutionnaires, Paris, Presses de la Fondation nationale des sciences politiques.

PAPAZIAN E. (2009), Manufacturing Truth : the Documentary Moment in Early Soviet Culture, Dekalh, Northern Illinois University Press.

SAMIER J. (2012), « L'aventure Cosmos » Distribution du cinéma soviétique en France entre 1978 et 1986, in Bulletin de l'Institut Pierre Renouvin, n³5, p. 77-88.

SCHNITZER L., SCHNITZER J. (1979), in Histoire du cinéma soviétique 1919-1940, Pygmalion/Gérard Watelet, Paris.

SORLIN P (2005), "Archives et actualités filmées de l'époque stalinienne », in Camera politique : cinéma et stalinisme, Feigelson Kristian (sous la direction de), Théorème n.8, Presses Sorbonne Nouvelle, p. 289-297.

STALINE J. (1977), Euvres XIV, 1934-1940, Paris, Nouveau bureau d'édition, 1977, p. 48-53.

UNFIELD B. (1999), "Montée et déclin des héros », in Centlivres P., Fabre D. et Zonabend F., La fabrique des héros, Paris, Editions de la MSH, p. 189-203.

VERAY L. (2011), Les images d'archives face à l’histoire, Chasseneuil-du-Poitou, Scérén-CNDP. 
19 Mariotti - A. G. StAkHANOv in Gaumont Pathé’s Soviet Film ArChives: Between Physical PERFORMANCE AND INSTRUMENTALISATION

VIGNE E. (1984), «Stakhanov, ce héros normatif », in Vingtième Siècle. Revue d'histoire, n¹, p. 2330.

WERTH N., BERELOWITCH A. (2011), L'État soviétique contre les paysans : Rapports secrets de la police politique (Tcheka, GPU, NKVD) 1918-1939, Paris, Tallandier.

This work is licensed under the Creative Commons Attribution-Non Commercial-Share Alike 4.0 International License. To view a copy of this license, visit http:// creativecommons.org/licenses/by-nc-sa/4.0/ or send a letter to Creative Commons, PO Box 1866, Mountain View, CA 94042 , USA. 